\title{
The Politics of Chaos in the Middle East
}

\author{
Olivier Roy
}

New York: Columbia University Press, 2008. 165 pages.

This relatively short and succinct book, written by a prominent French political analyst, offers an insight not only into post-9/11 American military and strategic dilemmas, but also a glimpse into the respective European conceptions and ways of thinking. Its main thrust is that the American reaction to the events of that day, far from producing an outcome in the image of a "hyperpower in a unipolar world," has instead bogged it down as a "power tied up in knots, incapable of policing the world" (p. 3). This "hopeless" situation, according to Roy, was brought on the Americans by themselves, rather than as a result of their enemies, be they the Taliban, al-Qaeda, or Iran (p. 3). While the American invasion of Iraq produced deep geostrategic transformations in the Middle East, these did not always produce the results that American decision makers had countenanced.

The United States continues to try to cope with a "no-win" situation in an "asymmetric" war, facing up to "impossible" choices, particularly as alQaeda continues to deploy in a deterritorialized and globalized world in which traditional instruments of power are rendered largely "ineffective." At 
the same time, China and Russia are increasingly engaging in global affairs as they seek to assert themselves as major powers (pp. 9-10). As a result, American credibility has been "damaged" by the outcome of the Bush administration's two major strategic errors: first, linking the retaliation for 9/11 to a "global war on terrorism" crusade, and second, making the invasion and occupation of Iraq, under a myriad of pretexts (e.g., spreading democracy), the "linchpin" of this new strategy. Apart from the administration's incompetence, such a way of thinking continues to inform the thinking of American neo-conservatives (pp. 3-4).

Roy contends that the Middle East's conflicts must be relocated in their own contexts, away from the existence of some "geostrategy of Islam" that allegedly explains all regional conflicts from Palestine and Bin Laden to the riots in the Paris suburbs (p. 7). In fact, he stresses that the Arab and Muslim worlds are undergoing their own dynamic of realliance, which puts the conservative Arab regimes (e.g., the Gulf sheikhdoms) in the same camp as Israel and thus pits them against a perceived Iranian or Shi $i$ threat (p. 8). As Roy puts it, the Saudis may not like the Israelis, but they have no real quarrel with them and so resort to anti-Zionist rhetoric only to maintain a semblance of legitimacy (p. 96).

The book is divided into a short introduction and four chapters. In the first chapter, Roy seeks to dispel myths and reorient perceptions so that he can better "define the enemy" and the "objective." Even before 9/11, according to him, the Bush administration had identified Saddam Hussein as the enemy, and thus Iraq was to be the battlefield; refused to admit that the Iraqi regime had no connection with international terrorism; and failed to martial enough military, political, and even propaganda resources toward achieving its goals (pp. 12-13). Roy depicts Bush's obsession with Iraq as part of a neoconservative "Greater Middle East" ideological agenda, rather than an imperial design (p. 27).

Having presumably dispelled this myth, he embarks upon challenging two more prevailing myths about oil and Israel: the American invasion of Iraq was neither defined by Israel nor by a wish to control Iraq's oil. As far as Israel was concerned, Iran (not Iraq) was the strategic enemy; therefore, Israel wanted Iran to be targeted (p. 24). As for oil, the United States had no interest in controlling oil fields or production; instead, it simply wanted to ensure the free flow of oil and the primacy of markets (p. 18). In this long chapter, Roy further attempts to puncture the notions that democracy can be imposed from above or by an external power (p. 39); that Islamists are the enemy (pp. 48ff), at least a viable one; and that European Muslims are incompatible with 
Europe. This latter notion of some "Eurabia" ultimately reconnects European Muslims to outside conflicts that barely affect them (p. 71).

Chapter 2 starts by discussing the presumption that there is a Muslim world at war with the West. There is no such world as a "Muslim world," according to Roy, particularly as Muslims are too busy fighting each other (p. 73). In this chapter, he links Islam with nationalism. He does not do this to insinuate the existence of what Bush designated "Islamic fascism," but to point out that Islamization becomes a strategic factor only when converging with another current - in this case, nationalism or some ethnic or mazhabi community (pp. 73ff). He argues that the political vision of pan-Arabism, despite its perceived failure, is alive as an emotive force even if it does not harbor political underpinnings (p. 91). Therefore, the region's new balance of power will be mainly between Sunnis and Shi as, the Arab countries and Iran, rather than Israel.

Recognizing that Iran will remain a major factor in the evolution of Middle Eastern crises, especially when it comes to nuclear power, chapter 3 examines the options of either negotiating with or bombing Iran. Roy seems to emphasize a policy of isolation instead of embarking upon a strike, whether by the Americans, the Israelis, or both. In all cases, as he puts it, the entire non-sensical concept of a global "war on terror" must be forsaken, for it leads to both misguided policies and perceptions and, for that matter, unpredictable outcomes (p. 140). Finally, chapter 4 deals with al-Qaeda. The author challenges the perception that this is some kind of territorialized organization of Arab mujahideen bent on expelling Christians and Jews from the Middle East in order to establish the caliphate (p. 141). He argues that al-Qaeda is a deterritorialized, global organization that is relatively distanced from Middle Eastern issues and with no political roots in the various Muslim populations (p. 142).

The purpose of Roy's analysis essentially is to dispel arguments or visions that there is a Muslim world out there, united under the banner of Islam and preparing to storm the West. In fact the Middle East, as he concludes, is more divided and debilitated than ever for such claims to make any sense (pp. 158-59). While the author certainly offers many insights and debunks various erroneous perceptions, parts of his analysis are incomplete or fail to look at the broader context. One example among others is when he argues that the United States is simply interested in the free flow of oil and the smooth functioning of oil markets, rather than in controlling its production. He ignores the global context in which controlling oil production and supplies may be a matter of the highest strategic concern, as Russia puts its 
house in order and China continues to emerge as a global and competing power increasingly dependent on oil imports. The neo-conservative agenda thus may not be purely ideological, and Iraq may not have been simply a Bush obsession.

From there, the so-called global "war on terror" may not be one solely against terrorism as such, but rather a strategic deception designed to shift attention away from the primary strategic goals toward a secondary target. In any case, Roy's effort remains laudable and his book certainly serves to offer an alternative view about different aspects of a major global conflict.

Amr G. E. Sabet Department of Public Management Vaasa University, Vaasa, Finland 